\title{
Revitalization as a synergistic effect
}

\author{
Katarzyna Szmygin \\ PhD student at the Department of Urban Design and Rural Landscape, \\ Warsaw University of Technology, e-mail: szmygin.katarzyna@gmail.com
}

\begin{abstract}
The development of modern cities is carried out in two main directions expanding the suburban structures and restoring the life of the existing building areas.

The growing problem that appears in discussions about the city is the revitalization, as evidenced by the fact of the entry into force October 9th 2015 the Act on revitalization. All definitions of revitalization emphasize its complexity and the fact that all activities must be carried out in an integrated and multidisciplinary way. Synergy is defined as an interaction of various factors, which effect is greater than the sum of separate actions. The alignment of those two definitions shows that revitalization is a synergistic effect. Effective revitalization is possible only when all the undertaken activities are coordinated. Therefore, all actions urban, architectural, social, economic, etc. must be considered and treated as equally important for the proper functioning of the area. Article will present revitalization as a synergistic effect and showing at the same time that only the synergy of individual actions can lead to effective revitalization.
\end{abstract}

Keywords: Revitalization, the city, coordination, urban planning, architecture.

\section{Introduction}

Polish cities are struggling with the increasing concentration of problems in the downtown areas, such as reduction of public spaces or their negligence, high noise levels caused by the lack of speed limits, traffic problems, insecurity, high level of degradation or not modernized infrastructure, adapted to today's requirements. The answer to this phenomenon is the escape of citizens to suburban areas. As a result, the city sprawls in an uncontrolled way and as a consequence we can observe a spatial chaos.

In order to keep the residents in the central areas local authorities decide to carry out revitalization programs in the municipalities areas.

These programs are aimed, in the long term, to remove the area out of crisis through multidisciplinary programs also known as synergetic.

\section{Definitions of revitalization}

With the entry into force of the Act of the revitalization October the $9^{\text {th }} 2015$, the term 'revitalization' has been finally defined. In accordance with the Act revitalization is a process for deriving from the state of crisis of degraded areas, carried out in a comprehensive manner, through integrated activities for the local community, space and economy, geographically concentrated, led by revitalizations stakeholders based on municipal regeneration program [1]. Before the entry into force in October 2016 of the Act, the term 'revitalization' did not appear in any law acts.

However, the definition of revitalization is to be found in many literature sources. All of them share some basic characteristics. First of all, each of them defines the revitalization 
as a continuous, multidisciplinary, long-lasting process and that helps the area get out of the crisis situation. This process takes into account in particular the spatial, architectural, technical, economic and social transformation.

The report of experts on sustainable development in March 1996 as the revitalization specifies the process of the economic reverse, social and physical disintegration of cities, in which that disintegration has reached a stage where market forces alone are not sufficient [2].

The German law by which the processes of revitalization throughout Germany are considered to be the most effective among the world defines revitalization as a process that will lead to overcoming the difficulties and problems in the urban fabric through appropriate transformations and corrective actions. Those preparations and the execution of the process must be subordinated to the public interest [3].

The crucial aspect, while considering the compatibility of revitalization programs with the requirements of the Integrated Regional Operational Program financed by the Structural Funds, is the definition given by Krzysztof Skalski (Assoc. Krzysztof Skalski professor of Jagiellonian University, member of the Program Council Regeneration Forum, a representative of Polish National Network of Cities Cittaslow in the Scientific Committee): A comprehensive program of renovation and modernization of buildings and public spaces, renovation of monuments on the selected area, usually the ancient district of the city, in conjunction with the economic and social development. Revitalization is a combination of technical measures, such as repairs, with the programs of economic recovery and action that help to solve social problems occurring in these areas: unemployment, crime, demographic imbalances. Thus, it is wrong to talk about the regeneration of one building or the revitalization of the city square, if those measures apply only to the modernization of buildings or the revalorization of monuments [4].

Important for the understanding the concept of revitalization it is the definition of Andreas Billert (Dr. Andreas Billert - Art historian, a specialist in the management of development projects and urban renewal. During the period 1967-1980: researcher at the Laboratory of Conservation and the assistant of the professor at the A. Mickiewicz University in Poznan. Since 1980 in Germany: in the period 1980-2008 employee at the State Conservation Office in Stuttgart, manager of the urban renewal projects in Lübeck and the Land of Brandenburg, researcher at European University Viadrina in Frankfurt an der Oder, an expert on German-Polish program TRANSFORM and Head of the EU program 'modern management of urban development'), that claims that it is a complex process of renewal of the urban area, which space, functions and substance have undergone a structural degradation, that has caused a state of crisis, precluding or significantly hindering the regular economic and social development of the area, and the sustainable development of the entire city. [5] This kind of approach to the problem shows that the area which requires the revitalization is no more able to develop properly. Hence false belief that each problematic and degraded area is eligible for the revitalization program.

\section{Definitions of synergy}

The concept of synergy is used virtually in every field. It derives from the Greek 'son' - together and 'ergon' - operation. It is the cooperation of many factors, or the parts of a complex system, resulting in a new value, new features and additional advantages. The sum of the actions of the individual components is greater than the effect of each individual.

Crucial for the understanding of this concept is to realize that each of these factors must meet the requirements set for themselves, as well as create an integrity. 
While speaking of synergy it should be mentioned that there exist two types of this phenomenon - positive synergy (plus) and the synergy negative (minus). The first occurs when the sum of the connected components has the effect objectively desired, whereas the second - when that accumulation causes adverse effect.

Nowadays, the concept of synergy is mistakenly interpreted as a combination of any selected factors. However, it must be remembered, that this phenomenon occurs only in case of intentional selection. Only accurate connection is able to guarantee the desired effect.

While defining the concept appears to be predictable, the measurement of its effects is very complicated. This requires carrying out the experiments that exclude any negative impact of external factors that could affect the final result. It is usually a very difficult thing, and the main factor impeding is the passage of time between the combination of the factors and obtaining the results.

\section{Examples of revitalization actions as synergistic}

Confronting the above definitions we can get the impression that the revitalization and synergy are complementary phenomena. This way of thinking promotes performing the revitalization activities and their analysis.

An example of a successful revitalization process is the city of Szczecin. The basis for all action in the city were created in 1992 as The strategy of renovation the downtown of Szczecin. The program of revitalization of the city assumed the recovery of 56 quarters situated in the historical city center[6]. Due to the complexity of that project, the article will focus on a single example - a pilot restoration of turzyński quarter number 27 , which has started in 1993.

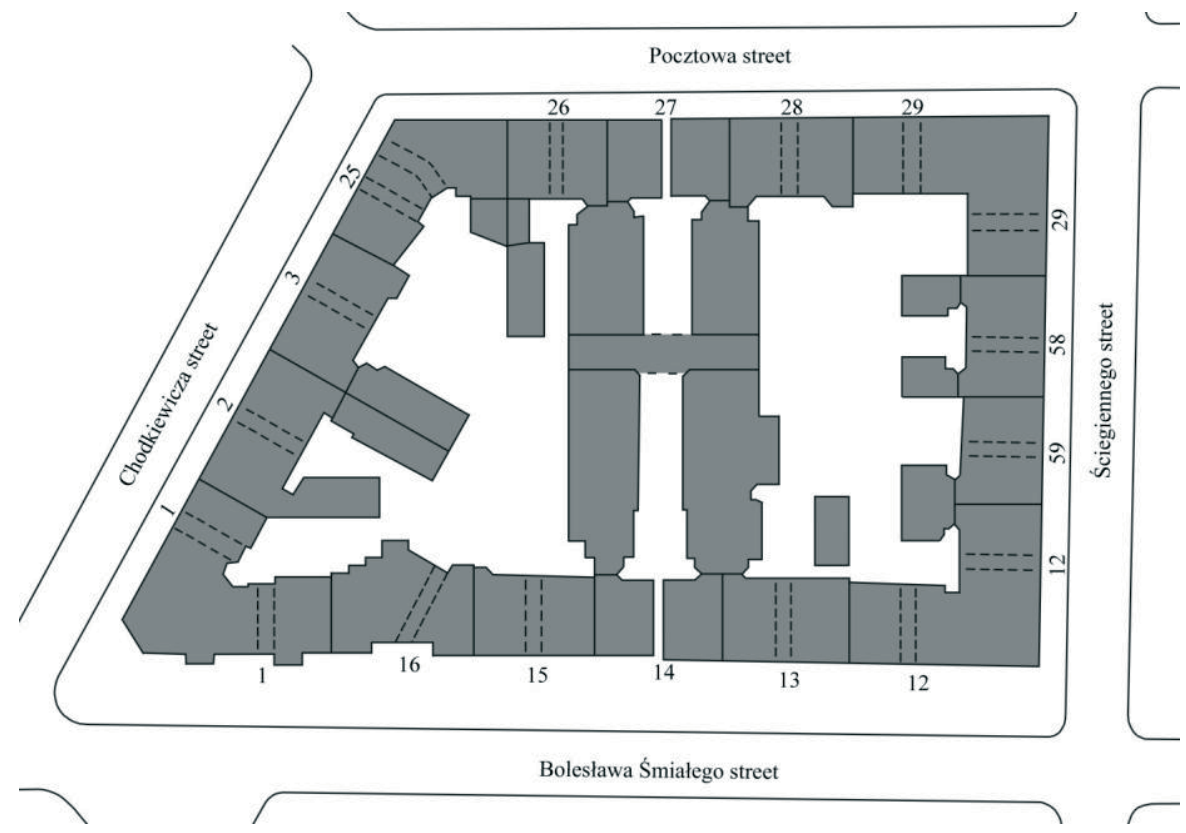

Fig. 1. The plan of turzyński quarter number 27

The quarter has been chosen as an example because of its location - right next to the heating station and the possibility of the implementation of the infill buildings [7]. 
Due to the complexity of the project the realization is considered to be very successful. Not only the architectural and urban but also social, economic, business, etc. aspects were taken into account For the purposes of the program the city has carried out researches and analysis of residents requirements and needs. The citizens have been asked about their satisfaction with the space and environment, and how they evaluate the changes that occurred as a result of the revitalization of the quarter [8].

Undertaken revitalization activities include:

- Improvement of the insolation inside of the quarter through the demolition of some parts of buildings and the diversification of their height. This procedure also allowed to create the terraces and balconies,

- Improvement of the quality of the interiors, ex. elimination of the raking layout of the rooms, combining small apartments into larger ones to improve the quality of life of the residents,

- Renovation of the facades of the buildings with the maintenance of the historical elements,

- Renovation of decor elements inside of the buildings,

- Restoration of historical items both inside and outside of the building.

- The usage of environmental solutions in the quarter - a ban on parking vehicles in the courtyard, a use of ecological materials, creating places in which the interaction and integration of local residents is possible,

- The usage of different sources of funding for the project - the cost was divided between the Municipality of Szczecin, the local community, Szczecin TBS(Social Housing Association of Szczecin) and credit KFM (The National Housing Fund).

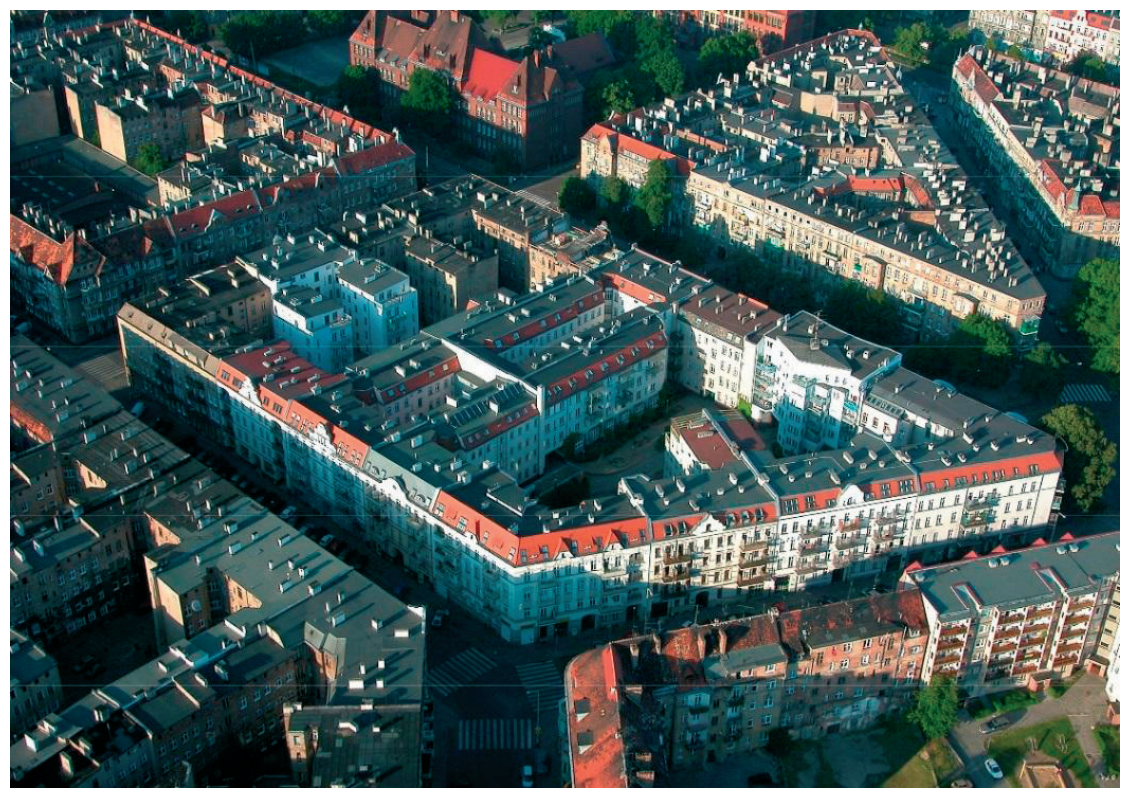

Fig. 2. Aerial view of turzyński quarter number 27, the author: Cezary Skórka

The second example of a comprehensive approach to the issue of revitalization is the document created July $24^{\text {th }} 2007$ - the Leipzig Charter on Sustainable European Cities. The Charter was established as a result of the meeting of ministers of the Member States of the European Union on urban development and territorial cohesion. 
The main objective of the Charter is to strive for the sustainable development of countries in the European Union through economic prosperity, social balance and a healthy environment taking into account the cultural, health aspects and institutional capacity of the Member States [9].

Means to achieve that objectives are to be both comprehensive strategies, as well as coordinated efforts of all stakeholders involved in the development of the city. These entities are both the government, local authorities and operators involved in the transformation of the city.

During the meeting, two basic priorities aimed at improving the functioning of cities were established:

I. An integrated approach to the urban development policy,

II. The inclusion of the poorer neighborhoods in the urban fabric.

The first goal may be executed by:

- Responding to the opinions of citizens and taking into account their needs and interests in the development process of the city,

- Combining knowledge with the funds,

- Carrying out accurate analysis of the situation of the city, for example. SWOT analysis,

- Treating the problems of urban development policy and the decisions taken at the level of a single city as a whole,

- Designing high-quality public spaces [10] (please be aware of the relationship between the cultural, economic, technological, social and environmental aspects. Since they are not independent aspects they should complete each other and able to function only after a skillful combination with each other),

- Respecting the context of places, especially historic buildings, existing public spaces, urban greenery, urban systems,

- Modernizing the infrastructure (adapting to the changing needs),

- Improving energy efficiency in the context of the sustainable development,

- Combining features. The experience of the past showed that the separation of functions (housing, work, education, entertainment) is not conducive to human interaction and causes the disappearance of a coexistence in society,

- Reducing the carbon dioxide emissions,

- Public education.

The second objective can be achieved by:

- Pursuing a policy of social housing,

- Responding to the causes of problems, not just their symptoms. Fighting against the effects of the problem does not solve it, only seemingly calms both the authorities as well as the society,

- Improving the quality of the physical environment by improving general standards in crisis areas,

- Strengthening the local economy and providing the residents from the degraded areas jobs,

- Introducing systems of education of children and youth,

- Improving the urban transport system and maintaining it at an inexpensive level.

Charter stresses the need for coordination of actions at all levels, without which the expected results cannot be achieved, meaning the city cannot develop in a sustainable way. Only by achieving synergy city can function properly. 


\section{Revitalization as synergy, synergy as revitalization}

Issues raised in the article are intended to provide answers to the basic question whether the synergy is a natural consequence of a successful revitalization or the revitalization by definition is a synergistic act. But the answer to this question cannot be given in a clear manner, because both of these statements are true.

Both cited definitions, examples of revitalization in Szczecin and the provisions of the Leipzig Charter show that the issue of synergy and revitalization are complementary. It is impossible to conduct a successful revitalization process without considering its complexity. At the same time only by obtaining the full synergy it is possible to carry out effective revitalization.

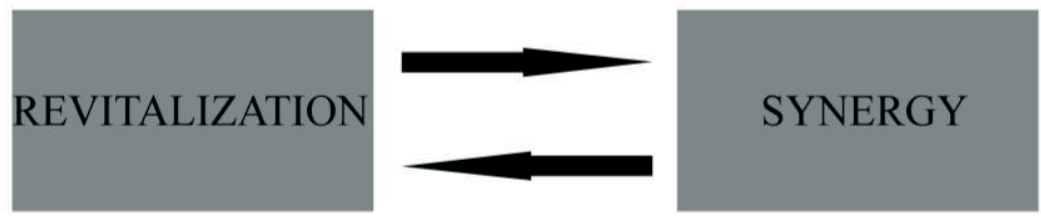

Fig. 3. Interaction between synergy and revitalization

The above diagram shows that the concepts should be seen as complementary to one phenomenon.

\section{Conclusions}

The article presented a close relationship between revitalization and synergy. Presented examples and definitions clearly show it. But these concepts cannot be treated as identical but auxiliary. Quarter building in Szczecin could be successfully revitalized only by achieving synergies. The provisions of the Leipzig Charter in advance have assumed coordination, meaning achieving synergetic effects.

Understanding the need of cooperation between all aspects during the execution of the revitalization programs will undoubtedly help their initiators conduct it in an efficient manner that will guarantee a success.

\section{References}

1. Act of October 9th 2015 for revitalization, The Journal of Laws of the Republic of Poland, Warsaw November 3rd 2015.

2. European Sustainable Cities Report, Expert Group on the Urban Environment, European Commission, Directorate XI, Brussels, March 1996.

3. Bryx M., Jadach-Sepioło A. (eds.). Rewitalizacja Miast Polskich, tom III - Rewitalizacja miast w Niemczech. Cracow 2009.

4. Skalski K. Rewitalizacja obszarów starej zabudowy w miastach. KIN, Cracow 2002

5. Billert A. Centrum staromiejskie w arach; problemy, metody i strategie rewitalizacji. Słubice 2004, p.6.

6. Collective work edited by Muzioł-Węcławowicz A. 'Rewitalizacja miast polskich' - tom XII 'Przykłady rewitalizacji miast' Cracow 2010, p. 24.

7. Ibidem p.28.

8. Ibidem p.32.

9. Leipzig Charter on Sustainable European Cities, May 24-25th 2007, p.2.

10. Ibidem p.4. 